\title{
Aetiology, clinical presentation and current treatment options of equine malignant melanoma - a review of the literature
}

\author{
Jessika-M. V. Cavalleri', Kathrin Mählmann², Patrick Steinigi and Karsten Feige \\ 1 Clinic for Horses, University of Veterinary Medicine Hannover, Foundation, Hannover, Germany \\ 2 Equine Clinic, University of Berne, Vetsuisse Faculty, Berne, Switzerland
}

\begin{abstract}
Summary: This review aims at giving an overview of the aetiology, genetic basis and clinical signs of equine malignant melanoma (EMM), the diagnostic work-up and the current treatment options. The established association between certain genetic features and melanoma formation in horses is reviewed. Typically, grey horses are affected with EMM. Typical predilection sites are the ventral tail, perianal region, eyelids, lips, parotid, or guttural pouches. Tumours usually grow slowly, but frequently metastasize eventually. Chemotherapy with cisplatin, 5-Fluorouracil and cimetidine are reviewed. Surgical excision of solitary small tumours can be successful, but has no systemic therapeutic effect and cannot prevent tumour recurrence. In conclusion, therapeutic options are still limited and conventional therapy is hardly curative. Current research focuses on immune modifying therapies using either tumour antigens for therapeutic vaccination or antitumoural interleukins. The most promising therapeutic approach currently under investigation is gene therapy using a xenogenic DNA vaccine coding for tumour associated antigens such as tyrosinase and gene therapy using interleukin-12 and - 18 .
\end{abstract}

Keywords: horse / neoplasia / vaccine / chemotherapy / immunotherapy / oncology

\begin{abstract}
Ätiologie, Klinik und aktuelle Therapieoptionen des equinen malignen Melanoms - eine Literaturübersicht
Die Prävalenz des equinen malignen Melanoms (EMM) liegt bei älteren Schimmeln bei etwa 80\%. Aufgrund ihres langsamen Wachstums und der häufig erst spät auftretenden Metastasierung werden Melanome beim Schimmel häufig in ihrer Malignität unterschätzt. Es wird jedoch derzeit davon ausgegangen, dass ein Großteil equiner melanozytärer (benigner) Tumore eine maligne Transformation durchmachen, sodass in der vorliegenden Übersicht allgemein der Begriff des equinen malignen Melanoms, wie von Moore und Kollegen 2013 empfohlen, verwendet wird. Die genetische Basis dieser Neoplasie ist inzwischen untersucht. Es besteht ein Zusammenhang zwischen der Entstehung von Melanomen und dem autosomal dominant vererbten Merkmal des Ergravens beim Schimmel. Die Heritabilität für die Entstehung von Melanomen bei Schimmel ist moderat und unterliegt einem polygenen Effekt. Die genaue Pathogenese ist allerdings noch nicht abschließend geklärt. Am häufigsten betroffen vom EMM sind Schimmel, aber auch Pferde anderer Rassen können erkranken. Die Tumore zeigen meist über längere Zeit ein langsames, oft infiltratives, Wachstum an typischen Prädilektionsstellen wie der Schweifunterseite, der Perianalregion, den Augenlidern, der Lippe, der Parotis oder den Luftsäcken. Häufig metastasieren die Tumoren aber in einem späteren Stadium doch. Häufig sind Signalement und klinisches Erscheinungsbild ausreichend um eine Verdachtsdiagnose zu stellen. Gesichert werden kann diese durch die zytologisch-histologische Untersuchung eines Feinnadelaspirats oder einer Biopsie. Therapeutisch kommen lokale Chemotherapeutika wie Cisplatin oder 5-Fluorouracil zum Einsatz. Auch die chirurgische Exzision ist bei solitären, kleinen Tumoren möglich. Allerdings wird durch diese lokalen Therapien kein systemischer Effekt erreicht, Metastasen werden also nicht beeinflusst. Auch ein Rezidiv des Tumors ist nach lokaler Therapie möglich. Da Melanome, nicht nur beim Pferd, sondern auch bei anderen Spezies, potenziell gut auf eine immunologische Therapie ansprechen, fokussiert sich die Forschung aktuell auf diese Therapieform. Cimetidin spielt diesbezüglich trotz einiger erfolgversprechender Untersuchungen beim Pferd eine untergeordnete Rolle. Am vielversprechendsten sind derzeit Untersuchungen zur Gentherapie mit einer xenogenen DNA-Vakzine gegen tumor-assoziierte Antigene (Tyrosinase) und die Gentherapie mit Interleukin-12 und - 18.
\end{abstract}

Schlüsselwörter: Pferd / Neoplasie / Vakzine / Chemotherapie / Immuntherapie / Onkologie

Correspondence: Dr. Jessika Cavalleri, University of Veterinary Medicine Hannover, Foundation, Clinic for Horses, Buenteweg 9 , 30559 Hannover, Germany, E-Mail: jessika.cavalleri@tiho-hannover.de

Citation: Cavalleri J.-M. V., Mählmann K., Steinig P., Feige K. (2014) Aetiology, clinical presentation and current treatment options of equine malignant melanoma - a review of the literature. Pferdeheilkunde 30, 455-460

\section{Introduction}

The common occurrence of equine malignant melanoma in grey horses has been known for decades (Mcfadyean 1933). The disease was recently reviewed (Metcalfe et al. 2013, Moore et al. 2013, Phillips and Lembcke 2013) and the term equine malignant melanoma (EMM) was proposed by Moore and colleagues (2013) to describe the common melanocytic disease occurring in horses, considering the malignant potential of this tumour during its course of disease. This review describes the aetiological basis of EMM, the genetic influence in its development, diagnosis, and the current therapeutic approaches. It concludes with an outlook of immunological treatment options which might prove a successful solution to this neoplastic disease in the future.

\section{Nature and clinical signs of EMM \\ Aetiological basis of EMM}

Cutaneous melanocytic tumours occur frequently in aged grey horses (Mcfadyean 1933, Fleury et al. 2000b, van der 
Zaag 2012). The aetiology of EMM has, however, been discussed controversially. Although some authors, predominantly in earlier research articles, suggested a non-neoplastic aetiology of the disease (Rodriguez et al. 1997, Sutton and Coleman 1997), EMM is now generally accepted as a neoplastic condition (Gorham and Robl 1986, Macgillivray et al. 2002, Patterson-Kane and Ginn 2003, Seltenhammer et al. 2004, Moore et al. 2013). Due to the high incidence of malignancy in equine melanomas Moore and colleagues (2013) proposed to use the term equine malignant melanoma when referring to equine melanomas because of their general malignant potential (Moore et al. 2013). Since most melanomas undergo a transformation from benign to malignant, within this review article the authors follow their recommendation and use the term EMM. Greying with age is due to an autosomal dominant trait which has been linked to melanoma formation in horses (Rieder et al. 2000, Selten-
Goetz et al. 1990, Schott et al. 1990, Blanchard et al. 1991, Fleury et al. 2000a, Garvican et al. 2007). However, histopathological differentiation between benign and malignant lesions is not always possible.

\section{Clinical signs in diseased horses}

Grey horses of a median age of 7.6 years are typically affected and the incidence of EMM increases with age. McFadyean (1933) has already described an EMM prevalence of $80 \%$ in horses older than 15 years of age. Melanomas often show a slowly invasive growth pattern, but frequently metastasize with disease progression (Baker and Leyland 1975, Valentine 1995, Fleury et al. 2000a, Smith et al. 2002). EMM usually starts with small solitary dermal tumours at various cutaneous (ventral tail, perianal region, eyelid, lip) or
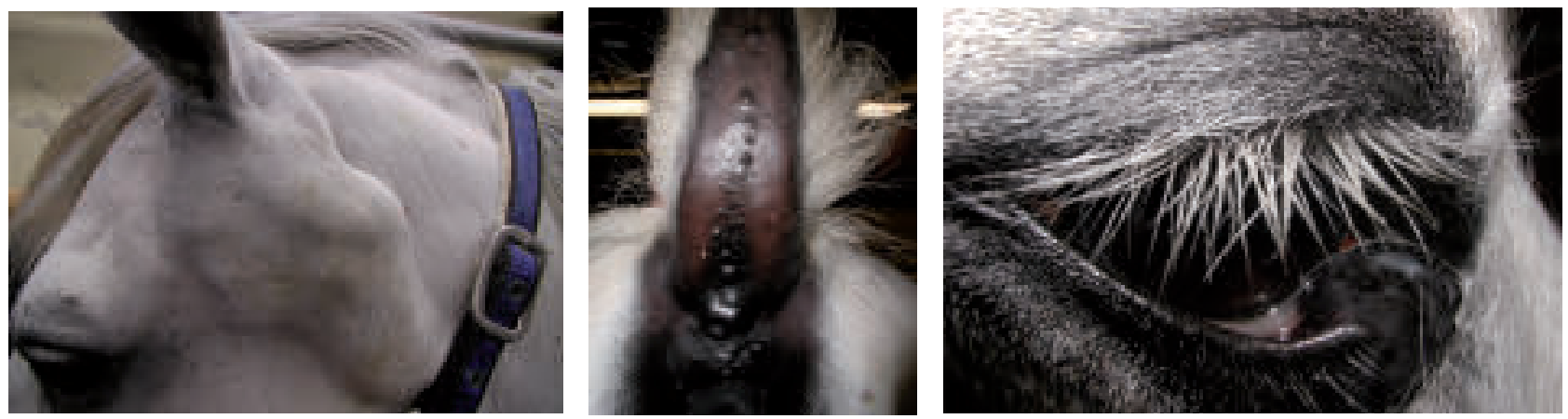

Fig. 1 Typically, equine malignant melanoma can be found at predilection sites as the parotid (A), under the tail (B) and the eyelid (C). Typisches klinisches Bild von Patienten mit Melanomen im Bereich der linken Ohrspeicheldrüse (A), Melanomen unter der Schweifrübe (B) und Melanom am linken Unterlid (C)

hammer et al. 2003, Rosengren Pielberg et al. 2008, Sundstrom et al. 2012b). Recently, a possibly causative association between a copy number expansion of the duplication in syntaxin 17 (duplicated sequence of the grey gene) and melanoma development was identified (Sundstrom et al. 2012a). In addition, a loss-of-function mutation of the agouti signalling peptide (ASIP) locus was shown to be associated with the occurrence of melanoma in grey horses (Rosengren Pielberg et al. 2008). The heritability for melanoma development in grey horses is moderate (Seltenhammer et al. 2003, Curik et al. 2013) and underlies a polygenic effect, which still has to be elucidated in detail. Recently, Teixeira and colleagues (2013) evaluated the prevalence and severity of EMM in a population of grey quarter horses.

The exact pathogenesis of tumour development has also still to be clarified. Since there are two genes (STX17 and ASIP) identified already in the development of EMM which code for proteins interacting with cell cycle regulator proteins, a dysregulation and subsequent proliferation and transformation might result from these gene products (Rosengren Pielberg et al. 2008).

Campagne et al. (2012) recently identified an overexpression of the receptor for activated $C$ kinase 1 (RACK 1 ) in equine melanoma cells compared to healthy melanocytes. This makes RACK1 a suitable marker for malignancy in EMM. Despite frequent occurrences of metastases, organ dysfunction due to internal metastases is rare (Mcfadyean 1933, visceral (guttural pouch, parotid) predilection sites (Figure 1). Visceral metastases can occur not only in parenchymal organs (Figure 2), bone-marrow and mesentery, but also in skeletal muscle (Rodriguez et al. 1998, Patterson-Kane et al. 2001, Macgillivray et al. 2002, Kovac 2005, Garvican et al. 2007). Masses may compress the peripheral nerves (Murray et al. 1997) or the spinal cord and, therefore, lead to neurologic deficits (Patterson-Kane et al. 2001, Rosengren Pielberg et al. 2008). Moore et al. (2013) proposed a clinical classification into four progressing stages in which horses showing only a single melanoma with a diameter of less than $2 \mathrm{~cm}$ and a slow growth is classified as stage 1 . Stage 2 describes horses with multiple small (less than $2 \mathrm{~cm}$ ) tumours without dissemination or metastases and a slow or quiescent growth pattern. Animals showing multiple melanomas less than $4 \mathrm{~cm}$ in diameter with dissemination or metastases and a slow growth rate are classified as stage 3 . Those multiple melanomas with a diameter of more than $4 \mathrm{~cm}$ and a rapid growth are classified as stage 4 .

\section{Diagnosis}

Despite the signalment, the clinical presentation in most cases is typical (when cutaneous tumours are found in grey horses at typical predilection sites) and allows a suspicion diagnosis of EMM. However, other equine tumours (e.g. equine sarcoids) can occur at sites known for EMM formation (e.g. prepuce). Therefore, histology or fine needle aspirates may help to con- 
firm the diagnosis in cases of doubt. To obtain a fine needle aspirate, a $20 \mathrm{G}$ needle is introduced into the tumour, while the horse is medically or manually constrained. A $10 \mathrm{ml}$ syringe is then attached to the needle and cells are freed from the tumour tissue by gentle negative pressure. Care should be taken to avoid bleeding into the sample. The aspirate can subsequently be streaked out onto a microscope slide and evaluated.

A transrectal palpation should be performed in cases in which the perianal region is involved in the disease process or in which the horse presents for more unspecific findings to identify possible abdominal metastases and, more importantly, to evaluate the interference of tumours with defecation. Since parotid melanomas may grow internally without severe external signs, an endoscopic examination of the upper airways and guttural pouches helps to identify potential obstructions in cases in which horses present for melanomas in the parotid region.

\section{Treatment options of EMM}

A number of local treatment modalities have been applied to EMM with varying success. Up to now, no single therapy has resulted in a satisfactory effect. Chemotherapy using cisplatin is a promising approach, outcome in grey horses ranges from partial remission of tumours to complete resolution of treated tumours for at least two years (Hewes and Sullins 2006, Theon et al. 2007, Spugnini et al. 2011). Cisplatin is usually mixed with sterile medical-grade sesame oil for local intratumoural injection in order to hold the substance on the spot (Goodrich and Semevolos 2000). A syringe containing cisplatin $(10 \mathrm{mg} / \mathrm{ml})$ is connected to a three-way stopcock. Double the volume of the aqueous cisplatin solution is drawn up into another syringe and the two fluids are mixed well. After antiseptical preparation of the injection site, the tumour and peritumoural region are infiltrated with the cisplatin
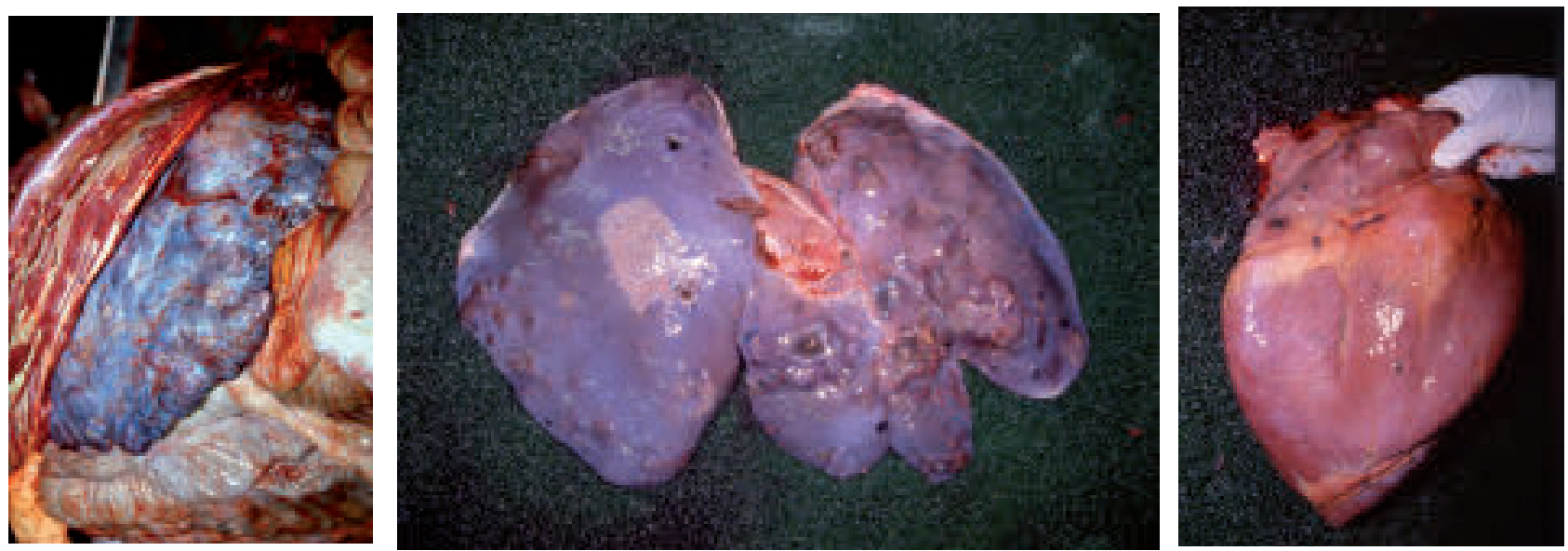

Fig. 2 After malignant transformation visceral metastases can be found. On post-mortem multiple metastases in the spleen (A), in the liver (B) and on the serosal surface of the heart (C) can be noted as distinct black nodules.

Viszerale Metastasen können in der Milz (A), dem Herzen (B) und in der Leber auftreten (C). Makroskopisch fallen sie bereits durch die starke schwarze Pigmentierung auf.
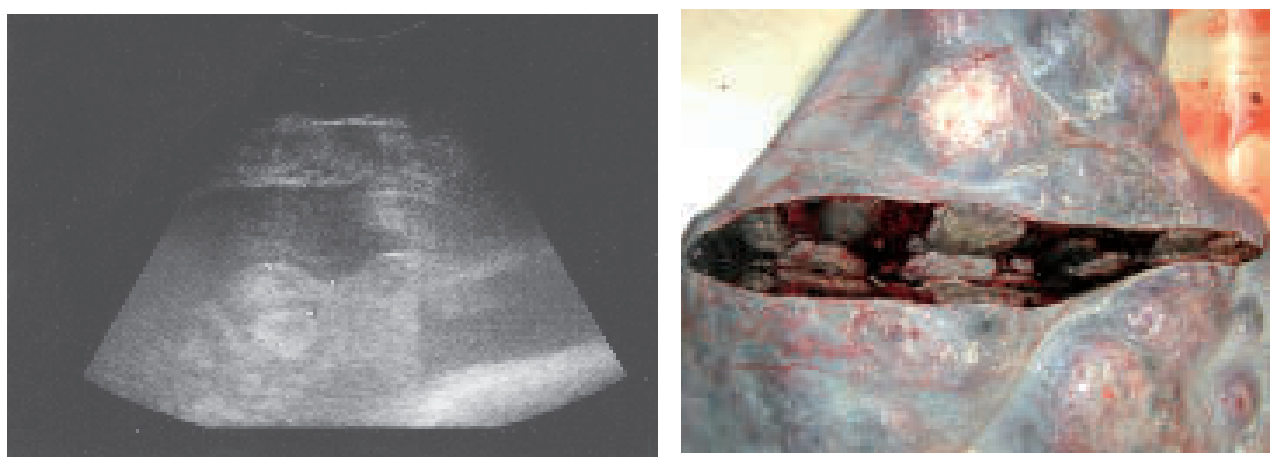

Fig. 3 Malignant melanoma of a grey gelding. The ultrasonographic image (A) was obtained in the ventral midline. The hypoechoic free fluid was diagnosed as haemoperitoneum on post mortem. The spleen has an irregular surface and shows multiple round hyperechoic nodules with hypoechoic margins. The corresponding post mortem image shows multiple metastases inside the spleen (B).

Die Milzmetastasen eines malignen Melanoms bei einem Schimmelwallach sin dim Ultraschallbild (A) erkennbar. Das Bild wurde ventral in der Linea alba. Die hypoechogene freie Flüssigkeit wurde postmortal als Hämoperitoneum diagnostiziert. Die Milz zeigt eine unregelmässige Oberfläche mit rundlichen hyperechogenen Herden, die von einem hypoechogenen Saum umgeben sind. Abbildung (B) zeigt den Sektionsbefund der Milz. Multiple Melanommetastasen sind unter der Oberfläche und im Anschnitt zu erkennen.

If the tumour has metastasized widely, the horse might present for unspecific signs, such as weight loss, colic or exercise intolerance. In these cases, a full work-up, including ultrasonography of the thoracic and abdominal cavity (Figure 3), radiography of the thorax, haematology, and blood biochemistry, might be necessary to find a suspicion diagnosis. Molecular markers such as RACK1 might play a role in diagnosing EMM in the future (Campagne et al. 2012). emulsion $(3.3 \mathrm{mg} / \mathrm{ml})$. It is recommended to use $1 \mathrm{mg}$ cisplatin per $\mathrm{cm}^{3}$ of tumour (Goodrich and Semevolos 2000). Appropriate safety measures (gloves and glasses) should be worn by all personnel involved in the treatment to avoid contamination of healthy skin with cisplatin.

Local treatment using only biodegradable beads containing cisplatin was successful in the treatment of grey horse melanomas, alternatively in combination with surgical debulking 
or with local intra- and peritumoural injection of cisplatin in sesame oil, respectively, leading to the resolution of the tumour treated for at least two years in most of the cases (Hewes and Sullins 2006, Theon et al. 2007). A case report describing intralesional cisplatin injection combined with electroporation showed partial remission of the tumours (Spugnini et al. 2011).

Chemotherapeutic use of 5-Fluorouracil in combination with surgical excision of a retrobulbar grey horse melanoma was reported by Bienert-Zeit and colleagues (2014). After surgical removal of the tumour via dorsal orbitotomy, $10 \mathrm{ml} 5$-Fluorouracil $(50 \mathrm{mg} / \mathrm{ml})$ were instilled into the surgical wound. The horse was followed for six months post surgery and no clinical evidence of recurrence at the surgical site or significant growth of a distant tumour (perianal) were observed during that time. The drawback of any local therapy is, however, that tumour growth at distant sites cannot be prevented and there is still a risk of recurrence of tumour growth after therapy (Theon et al. 2007).

The histamine 2 receptor antagonist cimetidine was reported as a successful treatment of EMM (Goetz et al. 1990). However, more recent reports did not confirm the favourable outcome in horses treated with cimitidine (Macgillivray et al. 2002, Laus et al. 2010).

\section{Surgical treatment}

Surgical excision may be a reasonable treatment method in early cases. However, it carries the risk of regrowth or an increase in the number of cutaneous lesions after surgery (Figure 4) (Moore et al. 2000, Rowe and Sullins 2004). Occurrence of internal metastases after surgery has not been reported in horses after excision of EMM. Nevertheless, MacGillivray et al. (2002) reported on necropsy findings of 14 horses with metastatic melanoma. In three of these horses, surgical debulking and partial tail amputation was performed 1.5 to 6 years before metastatic disease was diagnosed. It is, however, not clear whether the metastases found at post mortem examination were true metastases or multiple primary tumours, nor whether the tumours occurred only after surgery or had been developing despite surgical treatment. McMullen (2008) reported a 14-month recurrence-free period after enucleation of an eye and associated epibulbar melanoma. Few articles on iridal melanomas treated by sector iridectomy with or without systemical cimetidine treatment report favourable outcomes after surgery. In one of these cases, three melanotic lesions at different anatomical sites are described at an examination six weeks after surgery. It is not clear, however, whether those tumours had not been noticed before because of new growth or neglect (Scotty et al. 2008). After surgical removal and repeated systemic cimetidine therapy, the horse remained free of tumours for a follow-up period of 15 months. Tóth and colleagues (2011) claim sector iridectomy successful in the removal of an ocular melanoma, but do not mention a follow-up period at all. Therefore, no conclusion regarding long-term success can be drawn from the case.

In conclusion, long-term outcome of surgical excision alone is not satisfactory in many cases due to the only local effect of excision and frequently ongoing disease progression. It can, thus, only be recommended in solitary tumours or in cases of disturbed physiological functions due to tumour growth, as it is often unrewarding in advanced disease. Since another drawback of surgical therapy is the difficult surgical approach to predilection sites (perianal, tail, guttural pouches, parotid) with a high potential for sequelae in woundhealing and for surgical site infections, a more systemically effective therapy with promising long-term effects is desired.

\section{Outlook on immune-modifying therapies}

Melanoma is a tumour with marked immunogenicity and, therefore, carries the potential of responding to immunemodifying treatments (Gyorffy et al. 2005, Wolchok et al. 2007). The immunological treatment approach to melanoma in horses was reported as early as 1924 when a grey horse bearing melanoma was treated using an autologous melanoma vaccine (Mertens 1924). Since then, several reports on immunotherapy of EMM have been published. Despite their promising therapeutic effect shown in a case series of 12 horses (Jeglum 1997) and a case report (Finocchiaro et al. 2009), autologous cancer vaccines are not commonly used therapeutically. One of the reasons might be the cost and labour-intensive method of the vaccine preparation for each individual patient. Hence, more generally applicable therapies are under research. Several interleukins can act as adjuvants stimulating immune effector cells to express their antitumoural efficacy (Overwijk et al. 2000, Colombo and Trinchieri 2002). Heinzerling et al. (2001) described a gene therapy with plasmids encoding human interleukin-12 in seven grey horses resulting in partial regression of melanomas. In a placebo-controlled study, 26 grey horses bearing melanomas were treated intratumourally with plasmids encoding equine interleukin-12 or -18. Treatment with both interleukins resulted in a halt of tumour growth and even a size reduction to $80 \%$ of the baseline volume in the horses treated with interleukin-12 after 64 days (Müller et al. 2011). The differentiation antigens glycoprotein 100 (gp 100) and tyrosinase proved to be therapeutic as melanoma vaccines in mice, dogs and men (Bergman et al. 2001, Gyorffy et al. 2005, Wolchok et al. 2007). To further improve the rather adjuvant interleukin therapy, a combination of DNA coding for interleukin-12 and -18 and DNA coding for human gp100 or tyrosinase was evaluated in 27 grey horses bearing melanomas. However, in this investigation by Mählmann (2012), the additional therapeutic vaccination with DNA vectors encoding either human gp 100 or human tyrosinase did not improve the antitumoural effect of interleukin-12 and - 18 DNA alone. Nevertheless, other authors have shown not only immune responses in healthy horses to the application of a commercially available melanoma DNA vaccine encoding human tyrosinase, licensed in the Unites States of America for the treatment of canine melanoma (Oncept, Merial Ltd., Athens, GA) (Lembkke et al. 2012), but also report tumour regression of grey horse melanomas after the off-label use of this vaccine (Phillips and Lembcke 2013). Consequently, the immunological therapeutic approach to EMM - potentially in combination with conventional therapies - is likely to have a significant impact in the future. Eventually, with the further development and refinement of new methods, a cure for this tumour might be forthcoming for the general equine practitioner. 


\section{References}

Baker J. R., Leyland A. (1975) Histological survey of tumours of the horse, with particular reference to those ofthe skin. Vet. Rec. 96, 419-422

Bergman P. J., Mcknight J., Novosad A., Chamey S., Farrelly J., Jeffers Y., Egan M., Craft D., Gallardo H., Riviere I., Wulderk M., Hohenhaus A., Houghton A., Wolchok J. (2001) Phase I trial of human tyrosinase DNA vaccination in dogs with advanced malignant melanoma. Clin. Cancer Res. 7, 3754S-3754S

Bienert-Zeit A., Nordemann E., Von Borstel M., Wohlsein P., Iseringhausen M., Hellige M., Rötting A. (2014) Unilateral exophthalmos in a horse - Diagnosis, management and outcome. Pferdeheilkunde 30, 81-90

Blanchard T. L., Schumacher J., Edwards J. F., Varner D. D., Lewis R. D., Everett K., Joyce J. R. (1991) Priapism in a stallion with generalized malignant melanoma. J. Am. Vet. Med. Assoc. 198, 1043-1044

Campagne C., Jule S., Bernex F., Estrada M., Aubin-Houzelstein G., Panthier J. J., Egidy G. (2012) RACK1, a clue to the diagnosis of cutaneous melanomas in horses. BMC Vet. Res. 8, 95

Colombo M. P., Trinchieri G. (2002) Interleukin-12 in anti-tumor immunity and immunotherapy. Cytok. Growth Fac. Rev. 13, 155-168

Curik I., Druml T., Seltenhammer M., Sundstrom E., Pielberg G. R., Andersson L., Solkner J. (2013) Complex inheritance of melanoma and pigmentation of coat and skin in Grey horses. PLoS Genet. 9, e 1003248

Finocchiaro L. M. E., Riveros M. D., Glikin G. C. (2009) Cytokine-enhanced vaccine and suicide gene therapy as adjuvant treatments of metastatic melanoma in a horse. Vet. Rec. 164, 278-279

Fleury C., Berard F., Balme B., Thomas L. (2000a) The study of cutaneous melanomas in Camargue-type gray-skinned horses (1): clinical-pathological characterization. Pigm. Cell Res. 13, 39-46

Fleury C., Berard F., Leblond A., Faure C., Ganem N., Thomas L. (2000b) The study of cutaneous melanomas in Camargue-type gray-skinned horses (2): epidemiological survey. Pigm. Cell Res. 13, 47-51

Garvican E. R., Elce Y. A., Woolard K., Blikslager A. T. (2007) Preputial melanoma with systemic metastasis in a pony gelding and disseminated metastatic melanoma in a Thoroughbred gelding. Equine Vet. Educ. 19, 312-315

Goetz T. E., Ogilvie G. K., Keegan K. G., Johnson P. J. (1990) Cimetidine for treatment of melanomas in three horses. J. Am. Vet. Med. Assoc 196, 449-452

Goodrich L. R., Semevolos S. A. (2000) How to prepare and inject cisplatin in oily emulsion to treat equine sarcoids and squamous cell carcinomas. 46th AAEP annual convention, San Antonio

Gorham S., Robl M. (1986) Melanoma in the Gray Horse - the Darker Side of Equine Aging. Vet. Med. 81, 446-448

Gyorffy S., Rodriguez-Lecompte J. C., Woods J. P., Foley R., Kruth S., Liaw P. C., Gauldie J. (2005) Bone marrow-derived dendritic cell vaccination of dogs with naturally occurring melanoma by using human gp100 antigen. J. Vet. Intern. Med. 19, 56-63

Heinzerling L. M., Feige K., Rieder S., Akens M. K., Dummer R., Stranzinger G., Moelling K. (2001) Tumor regression induced by intratumoral injection of DNA coding for human interleukin 12 into melanoma metastases in gray horses. J. Mol. Med -J. M. M. 78, 692-702

Hewes C. A., Sullins K. E. (2006) Use of cisplatin-containing biodegradable beads for treatment of cutaneous neoplasia in equidae: 59 cases (2000-2004). J. Am. Vet. Med. Assoc. 229, $1617-1622$

Jeglum K. A. (1997). Melanomas. Current Therapy in equine Medicine. N. E. Robinson. Philadelphia, Pennsylvania, W.B. Saunders Company, 399-400

Kovac M. (2005) Aortic valve insufficiency and myocardial melanoma in a horse. Pferdeheilkunde 21, 408-412

Laus F., Cerquetella M., Paggi E., Ippedico G., Argentieri M., Castellano G., Spaterna A., Tesei B. (2010) Evaluation of cimetidine as a therapy for dermal melanomatosis in grey horse. Israel J. Vet. Med. 65, 48-52
Lembcke L. M., Kania S. A., Blackford J. T., Trent D. J., Odoi A., Grosenbaugh D. A., Fraser D. G., Leard T., Phillips J. C. (2012) Development of Immunologic Assays to Measure Response in Horses Vaccinated with Xenogeneic Plasmid DNA Encoding Human Tyrosinase. J. Equine Vet. Sci. 32, 607-615

Macgillivray K. C., Sweeney R. W., Del Piero F. (2002) Metastatic melanoma in horses. J. Vet. Int. Med. 16, 452-456

Mählmann K. (2012) Minimalistic immunologically defined gene expression T helper cell 1 (MIDGE-Th1) vectors coding for Interleukin 12 and -18 in combination with the transfection agent SAINT-18 have systemic antitumoral effects on equine melanomas. Diss. Med. Vet. Hannover

McFadyean J. (1933) Equine melanomatosis. J. Comp. Pathol. Ther. 46, 186-188

McMullen R. J., Clode A. B., Pandiri A. K., Malarkey D. E., Michau T. M., Gilger B. C. (2008) Epibulbar melanoma in a foal. Vet. Ophthalmol. 11 Suppl 1, 44-50

Mertens V. E. (1924) Aktive Immunisierung gegen ein Sarkom (Melanom eines Schimmelpferdes.). Deutsch. Zschr. Chir. 187, $216-$ 245

Metcalfe L. V., O'brien P. J., Papakonstantinou S., Cahalan S. D., Mcallister H., Duggan V. E. (2013) Malignant melanoma in a grey horse: case presentation and review of equine melanoma treatment options. Ir. Vet. J. 66, 22

Moore C. P., Collins B. K., Linton L. L., Collier L. L. (2000) Conjunctival malignant melanoma in a horse. Vet. Ophthalmol. 3, 201-206

Moore J. S., Shaw C., Shaw E., Buechner-Maxwell V., Scarratt W. K., Crisman M., Furr M., Robertson J. (2013) Melanoma in horses: Current perspectives. Equine Vet. Educ. 25, 144-151

Müller J. M. V., Feige K., Wunderlin P., Hodl A., Meli M. L., Seltenhammer M., Grest P., Nicolson L., Schelling C., Heinzerling L. M. (2011) Double-blind placebo-controlled study with interleukin-18 and interleukin-12-encoding plasmid DNA shows antitumor effect in metastatic melanoma in gray horses. J. Immunother. 34, 58-64

Murray M. J., Cavey D. M., Feldman B. F., Trostle S. S., White N. A. (1997) Signs of sympathetic denervation associated with a thoracic melanoma in a horse. J. Vet. Int. Med. 11, 199-203

Overwijk W. W., Theoret M. R., Restifo N. P. (2000) The future of interleukin-2: enhancing therapeutic anticancer vaccines. Cancer J. Sci. Am. 6 Suppl 1, S76-80

Patterson-Kane J. C., Ginn P. E. (2003) Dermal malignant melanoma in a horse with multifocal pancytokeratin expression. J. Vet. Diagn. Invest. 15, 54-56

Patterson-Kane J. C., Sanchez L. C., Uhl E. W., Edens L. M. (2001) Disseminated metastatic intramedullary melanoma in an aged grey horse. J. Comp. Pathol. 125, 204-207

Phillips J. C., Lembcke L. M. (2013) Equine Melanocytic Tumors. Vet. Clin. North Am. Equine Pract. 29, 673-687

Rieder S., Stricker C., Joerg H., Dummer R., Stranzinger G. (2000) A comparative genetic approach for the investigation of ageing grey horse melanoma. J. Anim. Breed Genet. 117, 73-82

Rodriguez F., Forga J., Herraez P., Andrada M., Fernandez A. (1998) Metastatic melanoma causing spinal cord compression in a horse. Vet. Rec. 142, 248-249

Rodriguez M., Garcia-Barona V., Pena L., Castano M., Rodriguez A. (1997) Grey horse melanotic condition: A pigmentary disorder. J. Equine Vet. Sci. 17, 677-681

Rosengren Pielberg G., Golovko A., Sundstrom E., Curik I., Lennartsson J., Seltenhammer M. H., Druml T., Binns M., Fitzsimmons C., Lindgren G., Sandberg K., Baumung R., Vetterlein M., Stromberg S., Grabherr M., Wade C., Lindblad-Toh K., Ponten F., Heldin C. H., Solkner J., Andersson L. (2008) A cis-acting regulatory mutation causes premature hair graying and susceptibility to melanoma in the horse. Nat. Genet. 40, 1004-1009

Rowe E. L., Sullins K. E. (2004) Excision as treatment of dermal melanomatosis in horses: 11 cases (1994-2000). J. Am. Vet. Med. Assoc. 225, 94-96

Schott H. C., Major M. D., Grant B. D., Bayly W. M. (1990) Melanoma as a cause of spinal cord compression in two horses. J. Am. Vet. Med. Assoc. 196, 1820-1822 
Scotty N. C., Barrie K. B., Brooks D. E., Taylor D. (2008) Surgical management of a progressive iris melanocytoma in a Mustang. Vet. Ophthalmol. 11, 75-80

Seltenhammer M. H., Heere-Ress E., Brandt S., Druml T., Jansen B., Pehamberger H., Niebaver G. W. (2004) Comparative histopathology of grey-horse-melanoma and human malignant melanoma. Pigm. Cell. Res. 17, 674-681

Seltenhammer M. H., Simhofer H., Scherzer S., Zechner R., Curik I., Solkner J., Brandt S. M., Jansen B., Pehamberger H., Eisenmenger E. (2003) Equine melanoma in a population of 296 grey Lipizzaner horses. Equine Vet. J. 35, 153-157

Smith S. H., Goldschmidt M. H., Mcmanus P. M. (2002) A comparative review of melanocytic neoplasms. Vet Pathol 39, 651-678

Spugnini E. P., D'alterio G. L., Dotsinsky I., Mudrov T., Dragonetti E., Murace R., Citro G., Baldi A. (2011) Electrochemotherapy for the Treatment of Multiple Melanomas in a Horse. J. Equine Vet. Sci. $31,430-433$

Sundstrom E., Imsland F., Mikko S., Wade C., Sigurdsson S., Pielberg G. R., Golorko A., Curik I., Seltenhammer M. H., Solkner J., Lindblad-Toh K., Andersson L. (2012a) Copy number expansion of the STX1 7 duplication in melanoma tissue from Grey horses. B. M. C. Genomics 13, 365

Sundstrom E., Komisarczuk A. Z., Jiang L., Golovko A., Navratilova P., Rinkwitz S., Becker T. S., Andersson L. (2012b) Identification of a melanocyte-specific, microphthalmia-associated transcription factor-dependent regulatory element in the intronic duplication causing hair greying and melanoma in horses. Pigm. Cell Melanoma Res. 25, 28-36

Sutton R. H., Coleman G. T. (1997). Melanoma and the greying horse. RIRDC Res. Pap. Ser. 55, 1-27
Teixeira R. B., Rendahl A. K., Anderson S. M., Mickelson J. R., Sigler D., Buchanan B. R., Coleman R. J., Mccue M. E. (2013) Coat color genotypes and risk and severity of melanoma in gray quarter horses. J. Vet. Int. Med. 27, 1201-1208

Theon A. P., Wilson W. D., Magdesian K. G., Pusterla N., Snyder J. R., Galuppo L. D. (2007) Long-term outcome associated with intratumoral chemotherapy with cisplatin for cutaneous tumors in equidae: 573 cases (1995-2004). J. Am. Vet. Med. Assoc. 230, 1506-1513

Tóth J., Huthmann S., Dikker L. (2011) Therapie eines progressiven malignen Irismelanoms beim Pferd mittels Sektoriridektomie. Prakt. Tierarzt 92, 218-223

Valentine B. A. (1995) Equine melanocytic tumors: a retrospective study of 53 horses (1988 to 1991). J. Vet. Int. Med. 9, 291-297

van der Zaag E. (2012) Nodular skin problems encountered in a first-opinion equine clinic. Pferdeheilkunde 28, 697-701

Wolchok J. D., Yuan J., Houghton A. N., Gallardo H. F., Rasalan T. S., Wang J., Zhang Y., Ranganathan R., Chapman P. B., Krown S. E., Livingston P. O., Heywood M., Riviere I., Panageas K. S., Terzulli S. L., Perales M. A. (2007) Safety and immunogenicity of tyrosinase DNA vaccines in patients with melanoma. Mol. Ther. 15, 2044-2050

\section{Conflict of interest statement}

None of the authors of this paper has a financial or personal relationship with other people or organisations that could inappropriately influence or bias the content of the paper. 